\title{
AN "ADMINISTRATOR'S" VIEW OF INDONESIAN FOREIGN POLICY
}

\author{
Frederick Bunnel1
}

\begin{abstract}
Twenty Years Indonesian Foreign Policy, 1945-1965, 1 by Ide Anak Agung Gde Agung, is an administrator's view of Indonesian foreign policy from 1945 to 1965. In terms of his political-diplomatic career Ide Anak Agung Gde Agung would seem well qualified to write such an account. Born in 1921 the son of the Rajah of Gianjar in Bali, Agung enjoyed the benefits not only of aristocratic breeding, but a Dutch university education in Batavia. By 1948, three years after Sukarno and Hatta had proclaimed the independence of Indonesia, Agung had risen to the important, but controversial position of Prime Minister of the State of East Indonesia--the largest of the several states created at Dutch instigation to ensure Dutch predominance within the projected federal government of the United States of Indonesia. Gradually balancing his Dutch ties with a more pro-Republic orientation, Agung played a significant role in the multilateral diplomacy that ended the fighting and won independence for Indonesia at the subsequent Round Table Conference in the fall of 1949 .
\end{abstract}

Following service as Minister of Interior in the short-lived Hatta cabinet in 1950, Agung's Dutch sympathies won him assignment as Ambassador to Belgium. By 1955 he had also had ambassadorial assignments in Luxembourg, Portugal and France. The latter post led in 1954 to his selection as Indonesian observer at the Geneva Conference. In the summer of 1955 Agung attained the pinnacle of his vocation with his installation as Foreign Minister in the Burhanuddin Harahap cabinet. Upon the resignation of that caretaker cabinet in early 1956, Agung became a senior official in the Department of Foreign Affairs. Increasingly relegated to the periphery of policy-making during the transition to Guided Democracy, Agung's deepening antagonism toward Sukarno's policies prompted his dismissal in 1961 and subsequent imprisomment without trial. Only with the accession of Suharto to power in 1966 did Agung win release. After spending 1966-67 as a research fellow at the East-West Center in Hawaii, Agung resumed his diplomatic career as an assistant to Foreign Minister Malik and, since 1970, as Ambassador to Austria.

Even this sketch of Agung's career establishes him as a notable member of that second generation of the Indonesian political elite that first came to prominence during the 1945 revolution. More specifically, Agung belonged to a small, but influential right-wing group of former federalists who had, in varying degrees, cooperated with the Dutch before and during the revolution. Following independence Agung naturally became associated with what he terms the "center-right" segment of the elite of the parliamentary period. Approvingly tagged "responsible moderates" by American diplomats--and "administrators" by the political scientist, Herb Feith--Agung's center-right grouping shared a generally

1. (The Hague: Mouton \& Co., 1973). 
privileged background, legal-administrative political skills and a Western orientation. In foreign policy the "administrators" reconciled attachment to Indonesia's "active and independent" non-alignment with an unspoken, but pronounced Western bias. Tacitly looking to the American 7 th fleet for military protection, they also invited economic dependency on Western financial assistance and investment as the necessary price for sustaining both economic development and their own political power.

Given Agung's political orientation, it is not surprising that he chose the prototype "administrator," former Vice-President Hatta, to write the introduction to his book. Equally predictable are the purposes of this book. The first half of its nearly 600 pages seeks to demonstrate how during the pre-Guided Democracy years Dutch and American intransigence on the West Irian issue undermined the best efforts of "administrator" cabinets to solve the issue and thus prevent the rise to power of Sukarno and his communist backers. A subordinate theme recounts how the arrogance of Indian leaders reinforced the radicalizing consequences of the festering Irian question. Wounded by the patronizing rebuff of Nehru and Menon to his bid for an Afro-Asian leadership role, Sukarno responded increasingly to the charm and skill of Chou En-lai's diplomacy first displayed at the April 1955 Bandung Conference.

The second half of the book concentrates on detailing Sukarno's betrayal of non-alignment principles for a radical nationalist confrontation foreign policy. Most conspicuous in the "crush Malaysia" policy and the attendant estrangement from the United States, Sukarno's embrace of confrontation concurrent1y meant, as Agung stresses, the cementing of relations with both the PKI at home and Peking abroad. Agung furnishes no integrating concluding chapter to his bloated chronicle of Sukarno's betrayal of non-alignment. In a brief epilogue, however, he approvingly reports that the army's New Order has restored Indonesian foreign policy to its traditional and proper principles of an "active and independent" non-alignment with, he might have added, the familiar Western bias of the "administrators" of the 1950s.

As reflected in the brief recital of the book's contents, Agung has attempted much more than the conventional personal memoir. Driven by his evident personal and ideological bitterness toward Sukarno--as we11 as, perhaps, by a sales-minded publisher-Agung has sought to produce a general interpretive history of Indonesian foreign policy from 1945 to 1965. In order to lend credibility to his indictment of Sukarno, Agung is forced to devote half of his bulky 600-page chronicle to the Guided Democracy period. In prison through most of that period, Agung necessarily relies almost exclusively on Western secondary sources to patch together rather polemical, repetitive and even inconsistent chapters on subjects he knows largely second-hand. More seriously, his personal outrage with American Ambassador Jones " "supine" diplomacy toward Sukarno leads him into an unbalanced, incomplete and sometimes inaccurate portrayal of both Jones' role and the objectives of Washington's policy. There is, for example, little appreciation of the crucial importance of the Indonesian army in the thinking of all American officials.

Happily, the first part of the book tends to correct some of the inadequacies of the second part. Here at least intermittently Agung relies on personal experience to offer not only a fresh Indonesian vantage point on controversial moments in Indonesian foreign relations, 
but also some insight into Agung's own attitudes and behavior. We find him, for example, straining to counter his federalist reputation by challenging Kahin's picture of East Indonesia as just another Dutch puppet state. Later in discussing the foreign policies of the first Ali cabinet Agung registers his own pride in the Sukarno-Ali use of the Bandung Conference to enhance Indonesia's international prestige, even as he complains of their excessive concern with grandeur and domestic political advantage at the expense of warm relations with the West.

The most illuminating historical memoir in Agung's 1engthy chronicle is the chapter on his seven-month tenure as Foreign Minister in 1955-56. Drawing on some hitherto unpublished personal papers and recollections, Agung provides an informed and spirited defense of his handling of the dominant foreign policy preoccupation of the Harahap cabinet--the arranging and conduct of what proved to be the 1 ast bilateral Dutch-Indonesian negotiations on the already embittered dispute over West Irian. Held in Geneva during the winter of 1955, these talks constituted the final major effort of the "administrator" moderates to deprive Sukarno and his PNI and PKI allies of the inflammatory nationalist issue on which they could ride to political power. Stated more bluntly, and as Agung apparently understood at the time, failure to win concessions from The Hague at the Geneva talks would hasten the political decline of both the Indonesian moderates and their ambivalent Western allies.

Within days of his installation as Foreign Minister, Agung outlined his strategy for accomplishing this urgent preventive action. Closely paralleling the diplomatic strategy formulated by Hatta and Sjahrir during the revolution, Agung placed heavy reliance on convincing Holland's allies to persuade her to negotiate. While Agung's rapprochement efforts did soften the tone of Australian and American statements, he had no success in altering their basic position. In his personal meeting with Secretary Dulles, Agung encountered not only a familiar litany about Washington's neutrality, but a heated rejection of the suggestion that such neutrality worked to Dutch advantage. The only responsive Western capital was London. Reminiscent of the role thrust upon them in 1945-46, the British agreed to recommend to the Dutch to accept the Indonesian offer to negotiate.

Nicely illustrating the critical intersection of domestic politics and foreign policy, Agung reports that his diplomatic offensive also required a special appeal to President Sukarno. In what appears to have been one of Agung's few personal meetings with the President, Agung was gratified at Sukarno's consent to refrain from anti-Western oratory for the duration of the talks.

Together with the support registered at the April 1955 Bandung Conference it appears that Agung's diplomacy abroad and at home did, indeed, facilitate the October Dutch acceptance to convene talks. More decisive, however, was the Dutch urgency about negotiating a permanent basis for their economic privileges in Indonesia in the face of Indonesia's demand for the revision of the onerous terms of the Round Table Conference. While secondary to the West Irian priority, Agung viewed progress on the economic issue as crucial to his hopes for a modicum of agreement on West Irian.

What is most significant about Agung's account of his talks at Geneva with Dutch Foreign Minister Luns is not the substance of the negotiations, but Agung's urgent attempt to place the blame for their failure on Luns and Sukarno. 
Agung's castigation of the Dutch is motivated by much more than a retrospective effort at historical self-justification. Precisely because he looked to the Dutch as Indonesia's natural patron and ally, Agung was infuriated by the shortsightedness and intransigence that led the Dutch to destroy this last best chance for a mutually beneficial relationship with Indonesia's political moderates.

Agung also places major blame on the radical nationalist opposition in Djakarta led by Sukarno. Their public withdrawal of support for Agung spread into the cabinet itself and nearly forced the recall of Agung's delegation. While Harahap's political maneuvering could forestall that drastic step, the opposition's attacks also understandably weakened the Dutch incentive to negotiate seriously. What was most galling to Agung, however, was Sukarno's public violation of his personal pledge to Agung to refrain from anti-Dutch political attacks for the duration of the talks.

Agung's charge of political opportunism leveled at Sukarno loses its force, however, when juxtaposed with the volte-face that Agung and the moderates underwent following the breakdown of the Geneva talks. Confronted with the reality of the portentous political defeat that they had feared, Agung and the cabinet sought to salvage a modicum of political advantage by adopting the militant posture of the opposition they had so vigorously denounced. In a last-minute bid for political credits before the scheduled demise of their caretaker cabinet. Harahap and Agung declared the unilateral abrogation of the Dutch-Indonesian union. While justifiable anger and despair with Dutch and American intransigence certainly influenced this decision, Agung's own portrayal reveals the intrusion of domestic political motives. To compound this evidence of political opportunism dictating foreign policy positions, Sukarno and the PNI also reversed themselves by seeking to block parliamentary and Presidential approval of the cabinet's declaration. In this way the opposition hoped to ensure that the next cabinet under a PNI Prime Minister would reap the popularity inherent in gestures defying the Dutch. From the "administrators"" standpoint, there is an even deeper irony in this tale of petty opportunism. As Feith has warned, the adoption of militancy by Agung's moderates not only violated their professed allegiance to international law, but it gave Sukarno a telling precedent for the further unilateral actions of confrontation that Agung would find deeply abhorrent.

Even in this chapter on his own role as foreign minister, Agung neglects to deal with several pertinent issues already exposed in other accounts. In terms of the domestic political context of the Harahap cabinet, Agung completely avoids all mention of the role of the army. Instead he could have dealt with a critical, but largely unanswered question of the attempts of army leaders to influence the course of Agung's talks with the Dutch. Particularly during the January-February onslaught of opposition demands for supervision of the talks, one wonders whether any army leaders gave political backing to the beleaguered moderates, or did they follow the lead of the new Army Chief of Staff Nasution who reportedly had come to share Sukarno's view that West Irian could not be won through talks with the Dutch?

While of less political significance than illumination of the army's role, Agung might also have treated his own handing of the Ministry of Foreign Affairs. Precisely because of the "administrator's" reliance on diplomacy, especially with the West, one wonders what steps Agung took to improve the capabilities of the ministry. In that con- 
text, he could also have answered the allegations registered by Feith of far-reaching transfers of personnel for political reasons.

On a more theoretical plane, it is crucial to expose the limits of Agung's key assumptions about Indonesian political history. Three at least deserve brief mention. Most conspicuous is what might be called "the West Irian panacea thesis." At the core of this book, there is the widely shared view that if West Irian could have been settled, preferably no later than 1957 for Agung and somewhat later for other apostles of this notion, then the moderates would have triumphed over the extremists--i.e., the PSI and Masjumi or later the army would have checked the Sukarno-PKI advance to power. As Feith, Weinstein and others have contended, is it not more consistent with the character of Indonesia's political environment in the $1950 \mathrm{~s}$ and, indeed, on to the present day to assume that in the absence of the West Irian issue "functional equivalents" would have arisen as channels for the deep frustrations of a society stirred by nationalist and economic aspirations yet trapped in the syndrome of underdevelopment?

Agung's inattention to this possibility is indicative of more fundamental assumptions about the class and cultural roots of Indonesian politics. His is in the end a very narrow Western elitist view of Indonesian politics. Not only is there little sense in his book of the class element in the policy of the "administrators," there is also no evidence of a personal capacity to empathize with the poverty of the peasant masses. They remain a dim abstraction introduced only as an addendum to stereotype anti-communist allusions to the PKI and its mass support.

If the class dimension is absent from Agung's analysis, so is the cultural perspective. Hazardous as a cultural roots approach is to any politics, to ignore it is to flaw understanding. In his preoccupation with charting the surface movements of international politics, individual actors seldom appear more complex than their political positions. Agung's research into Western sources clearly left him indifferent to the seminal work of men such as Geertz and Benda. More fundamentally he has forgotten the potent role of ethnicity as he must have experienced it even at the level of elite politics.

To rebuke Agung for inattention to such theoretical perspectives is, however, unfair if we judge his book by the standard of personal memoir rather than scholarly history. That standard requires, above all, that the writer faithfully endeavor to reconstruct his participation in history "like it was." Library research may be necessary to stimulate recall of the sequence of events and their context, but it should not, in the first instance, provide the categories and questions of analysis. Uncontaminated recollection should be the unreachable objective. It is to Agung's credit that he has labored long to give both the scholar and the layman a substantial portion of his memoirs. May he extend them further into a full-fledged autobiography, such as Roeslan Abdulgani is currently attempting. And may Agung's effort be a spur to the Indonesian government to encourage and even subsidize other political figures to write their memoirs or at least give oral interviews. Perhaps most crucial here are the recollections of current political prisoners who, unlike Agung, may never enjoy either release from prison or the opportunity to write freely. 